\title{
Bireysel Finansmanda Etkili Bir Araç: Kredi Kartı Üzerine Ampirik Bir Araştırma
}

\author{
İpek CEBECI* ${ }^{*}$ \\ Selçuk $\mathrm{UÇAR}^{* *}$
}

\section{ÖZET}

Bu çalışma, bireysel finansman aracı olan kredi kartları üzerine ampirik bir incelemeyi içerir. Giresun Üniversitesi, Görele Uygulamalı Bilimler Yüksekokulu, Bankacılık ve Finans Bölümü lisans ögrencilerinin, sosyo-ekonomik yapıları, kredi kartı kullanım durumları, kredi kartına ilişkin tutumları incelemek hedeflenmiştir. Araştırma kapsamında kullanılan veriler, 2015 yılı bahar döneminde 232 öğrenciyle gerçekleştirilen anket çalışması yoluyla elde edilmiştir. Araştırma bulgularına göre; öğrencilerin \%46.1'i kredi kartı kullanmaktadır ve kredi kartı kullanan ögrencilerin \%71'inin sadece tek kartı bulunmaktadır. Çalışmada uygulanan faktör analizine 13 değişkenle başlanmış, analiz sonucunda 8 değiş̧ken 3 faktörde (duygusal boyut, davranışsal boyut, güven boyutu) toplanmıştır. Bu 3 faktörün varyansa yaptığ katkısı \%80.799'dur.

Anahtar Kelimeler: Kredi Kartı, Üniversite Öğrencileri, Faktör Analizi

JEL Sinıflandırması: C12, D12, G20

An Empiric Investigation On Credit Card: An Effective Instrument Of Personel Financing

\section{ABSTRACT}

This study consists an empiric investigation on credit card, which is an effective personal financing instrument. We aim to find out some of socio-economic structures, credit card use status and card usage trend of banking and finance students', located in Görele Applied School of Giresun University. The research findings showed that \%46.1 of the students use credit card and the majority of the students (71\%) have a single credit card. In this study, we applied factor analyses to our data. The opinions of students on credit card usage were interpreted by factor analyses which started with 13 variables and clustered under 3 (emotional dimension, behavioral dimension, confidence dimension) factors with 8 variables. The factor analaysis result showed that there were 3 factors explaining $80.79 \%$ of the total variance in the questionnaire.

Keywords: Credit Card, University Students, Factor Analyses

Jel Classification: C12, D12, G20

\footnotetext{
*Yrd. Doç. Dr. İpek Cebeci, Giresun Üniversitesi, Görele Uygulamalı Bilimler Yüksekokulu, ipek.cebeci@giresun.edu.tr

** Selçuk Uçar, Giresun Üniversitesi, Görele Uygulamalı Bilimler Yüksekokulu, selcuk_ucar.37@hotmail.com
} 


\section{GíRiş}

Kredi kartları mevcut ihtiyaçların giderilmesi amacıyla para yerine kullanılan bir ödeme aracı olup; tüketicilere taşıma ve kullanım kolaylığı sağlama, toplum içerisinde saygınlık kazandırma ve benzeri avantajlarından ötürü günümüzde oldukça yaygın bir kullanım seviyesine ulaşmış olan bireysel finansman aracıdır (Aşan, 2007: 3). Kredi kartlarının tüketiciye sağladığı ek kredi imkanı, nakit taşıma riskini ortadan kaldırması, alışverişlerde taksit olanağı sağlaması türünden olumlu özelliklerinin yanı sıra (Kaya, 2009: 120-129), tüketicinin gelecekte elde edeceği geliri, kartı kullandığı an itibarıla tüketiyor olması nedeniyle kontrolsüz kart kullanımı, kişinin aşırı borçlanması gibi olumsuz etkilere de yol açabilmektedir (Durukan vd. , 2005: 152).

Toplumun hemen hemen her kesiminin; emekli, işçi, öğrenci ve diğer kesimlerin sahip olduğu kredi kartları (Evans, 2004: 61), 1960'ler itibarıyla, dünyada yaşanan teknolojik gelişmelerin paralelinde kullanılmaya başlanmıştır (Cengiz, 2009: 180). Ülkemizde ilk kredi kartı 1968 yılında Koç grubu tarafından çıkarılmış, ancak kredi kartlarının tam anlamıyla yaygın kullanımı 1990'lı yılların ortalarını bulumuştur (Özkul ve Tapşın, 2010: 140). Son yıllarda ise ülkemizdeki kredi kartı kullanımı oldukça yüksek seviyelere ulaşmıştır. Bankalar, hızlı gelişen kredi kartı pazarında söz sahibi olabilmek için sıkı bir rekabet içerisine girmişlerdir. $\mathrm{Bu}$ rekabet ortamında bankaların mevcut ve potansiyel müşterisi konumunda olan, farklı sosyo-ekonomik gruplar üzerinde yapılmış çalışmaları takip ederek, özellikle bankaların pazarlama departmanlarının ürün ve hizmet geliştirecekleri beklenebilir. $\mathrm{Bu}$ düşünce doğrultusunda, bankacılık ve finans eğitimi gören genç yaş grubu üzerine yapılmış, üniversite gençliğinin kredi kartı sahiplik ve kart kullanımı ile ilgili durumu detaylı olarak incelemek amaçlanmıştır. Bu araştırma akademik literatüre güncel bir uygulama örneği katkısının yanı sıra, bankacılık ve finans alanında eğitim gören üniversite öğrencileri için yapılmış olması nedeniyle bir örnek teşkil etmesi açısından önem taşımaktadır.

\section{KREDİ KARTI KONUSUNDA LITTERATÜR TARAMASI}

Kredi kartı sahipliği ve kredi kartı kullanımına yönelik yapılan çalışmaların bazıları şu şekilde özetlenebilir:

\section{1. Öğrenci Grubu Dışındaki Çalışmalar}

Örücü (2003), kredi kartı kullanımının tüketici davranışlarına etkisini kamu kurumu çalışanları açısından incelemiş ve araştırma sonucunda kredi kartı kullanımının yaş, eğitim, gelir düzeyi ile ilişkisi olduğunu tespit etmiştir. Ayrıca kredi kartı tercihinde önde gelen etkenler olarak; uygulanan faiz oranı, kredi kartının sağladığı avantajlar ve nakit para kullanmamak olduğu belirlenmiştir.

Karamustafa ve Biçkes (2003), Nevşehir'de kredi kartına sahip olma ve kart kullanmada en etkili özelliklerin finansal kaynak oluşturma ve alışverişlerde kolaylık sağlama 
özellikleri olduğu görülmüştür. Kredi kartı kullanımında; cinsiyet, medeni hal ve aylık gelir dışındaki diğer bağımsız değişkenlere göre istatistiksel olarak anlamlı farklar bulunmuştur.

Çiçek ve Demirdelen (2010), akademisyenlerin kredi kartı tercihlerinin demografik özellikleri ile ortaya konulması ve kredi kartlarının harcamalar üzerindeki etkisinin, kredi kartı kullanım sıklığı ve kredi kartı kullanım alanları açısından yine katılımcıların demografik özellikleri kapsamında incelenmesi amaçlanmıştır. Bulgulara göre; maaşın aynı bankadan alınması ve bankanın imajı kredi kartı tercihinde daha çok etkili iken, yakınların tavsiyesi ve kartın harcama limitinin yüksek olmasının ise fazla etkili olmadığı görülmüştür. Erkeklerin kadınlara göre yüksek harcama limitli kartları tercih ettiği, kadınların ise daha çok hesap kesim tarihini önemsediği belirlenmiştir. Profesörler ve doçentler, yardımcı doçentlere göre kredi kartını veren kuruluşun imajını daha çok önemserken, doçent ve araştırma görevlilerinin taksit imkanları, profesör ve doçentlerin ise yüksek standartlı bir yaşam sunması nedeniyle tercih ettiği tespit edilmiştir.

Şener ve Güven (2005), yaşlıların kredi kartı kullanımlarına dair mevcut durumu belirlemek amacıyla bir çalışma yapmıştır. Yaşlılıkta elde edilen gelirin azalmasıyla birlikte mevcut yaşam standardını sürdürebilmek için ek bir kaynak olarak kullanılan kredi kartının bilinçli kullanılması için, yaşıı tüketicilerin bilgilendirilmesi gerektiği sonucuna ulaşılmıştır.

Oktay vd. (2009), kredi kartı kullanımının yaygınlığına ve kredi kartı sahipliğine etki eden faktörleri belirlemek için, Erzurum'da bir çalışma yapmış, kredi kartı sahipliğinde etkili olan faktörler olarak; meslek, aylık toplam gelir, alışverişte tercih edilen ödeme şekli, kredi kartının faydalı olduğu düşüncesi ve kredi kartlarının tüketimi artırdığı düşüncesi belirlenmiştir.

\section{2. Öğrencilere Yönelik Yapılan Çalışmalar}

Keskin ve Koparan (2010), üniversite öğrencilerinin sosyo-ekonomik ve demografik faktörlerinin kredi kartı sahipliği üzerindeki etkilerini logit model yardımıyla incelemiştir. Araştırmada incelenen değişkenler arasından; öğrencinin cinsiyeti, sınıf düzeyi, yaşı, kardeş sayısı, ailesinin ikamet ettiği şehirle üniversitenin bulunduğu şehir arasındaki uzaklık, hane halkının aylık geliri, öğrencinin aylık harcama tutarı ve öğrencinin nerede kaldığı değişkenleri kredi kartı sahipliğini belirleme üzerinde istatistiksel olarak anlamlı bulunmuştur.

Girginer vd. (2008), Eskişehir Osmangazi Üniversitesi İktisadi ve İdari Bilimler Fakültesi'nde öğrenimlerini gören öğrencilerin kredi kartı kullanımlarına yönelik tutumlarını boyutlandırmak ve bu boyutların cinsiyet, gelir, kredi kartı sahibi olup olmama durumu, sahip olunan kredi kartı sayısı gibi özelliklere göre farklılıklarının tespitini amaçlamıştır. 16 maddelik bir faktör analizinden 5 boyut (duygusal, kaygısal, kavramsal, davranışsal, güvenilirlik) tespit edilmiştir. Analizler sonucunda, öğrenciler arasında kredi kartına yönelik tutum boyutlarının hiçbirinde anlamlı bir farklılık bulunmamıştır. Öğrencilerin kredi kartı kullanımına yönelik tutumlarında duygusal ve güvenilirlik boyutlarında kredi kartı kullanan 
ve kullanmayanlar arasında ise anlamlı farklar bulunduğu ve gelir düzeyi düşük öğrencilerin daha düşük düzeyde kaygısal tutum gösterdikleri belirlenmiştir.

Suher vd. (2014), kredi kartı sahipliği ve kullanımına ilişskin tutum ve davranış faktörlerini belirlemek amacıyla üniversite öğrencilerine yönelik çalışma gerçekleştirmiştir. Çalışmada kredi kartı kullanımına yönelik 15 maddeli tutum ölçeği kullanılmıştır. Üniversite öğrencilerinin kredi kartı sahiplik ve kullanımı açısından memnuniyetinin pozitif yönde olduğu belirlenmiştir. Bulunan faktörler ile üniversitelerin bölgesel dağılımı, kredi kartı kullanım sıklığı ve sahip olunan kredi kartı sayısı değişkenlerinin ortalama farklarına bakılmış ve istatistiki olarak herhangi bir fark bulunmamıştır.

Gözener ve Sayılı (2013), Gaziosmanpaşa Üniversitesi Taşlıçiftlik yerleşkesindeki öğrencilerin kredi kartı kullanım durumları ve kredi kartı kullanımlarını etkilediği düşünülen faktörleri belirlemek için anket çalışması yapmıştır. Öğrencilerin kredi kartı kullanımlarında etkili olan faktörler ki-kare analizi ve kredi kartı kullanım hususundaki düşüncelerse faktör analizi ile değerlendirilmiştir. Ki-kare analizi sonucunda öğrencilerin eğitimi, ailelerin yerleşim birimleri, ailelerin gelirleri, öğrencilerin eline geçen para ve öğrencilerin ikametgah yerlerinin kredi kartı kullanımında etkili olduğu bulunmuştur. Faktör analizine ise 30 değişkenle başlanıp 25 değişkenle 3 faktör (avantaj, imaj ve dezavantaj) belirlenmiştir.

Can (2013), Meslek Yüksekokulu'nda eğitim gören öğrencilerin sosyo-ekonomik ve demografik özelliklerinin kredi kartı kullanımı üzerindeki etkilerini incelemiş ve yapılan analiz sonuçlarına göre; öğrencinin cinsiyetinin sahip olduğu kredi kartı sayısı üzerindeki etkisi anlamlı bulunmazken, öğrencinin yaşının sahip olduğu kredi kartı sayısı üzerindeki etkisi anlamlı bulunmuştur. Öğrencinin yaşı büyüdükçe sahip olduğu kredi kartı sayısında azalmanın olduğu görülmüştür. Öğrencilerin kredi kartı kullanım sürelerine bağlı olarak, harcama sonrasında yaşadıkları ödeme güçlügü ve diğer harcamalarda yaşadıkları sıkıntılar sonrasında edinilen tecrübelerle, daha fazla kredi kartı sahibi olmayı düşünmedikleri gözlemlenmiştir. Cinsiyetin ise, öğrencilerin sahip olduğu kredi kartı sayısı üzerinde etkisinin olmadığı görülmüştür. Mann-Whitney $U$ farklılık testi sonucunda belirtilen kredi kartı kullanım alanları açısından gıda ürünleri ve ulaşım harcamaları dışındaki yaptıkları harcamalar, öğrencilerin cinsiyetlerine göre, istatistiksel olarak anlamlı faklılık bulunduğu gözlemlenmiştir. Öğrencilerin kredi kartını alışveriş yapmayı tercih etme nedeni en fazla "kredi kartının puan biriktirmesi” olarak belirlenmiştir. "Öğrencinin nakit parasının olmaması", "taksit erteleme imkanının olması" ve "kredi kartı borcunu ailesinin ödemesi" gibi nedenler de kredi kartı ile alışveriş yapmayı tercih etme nedenleri arasındadır.

Yayar vd. (2011), Gaziosmanpaşa ve İnönü Üniversitesi’nde anket çalışması yaparak, üniversite öğrencilerinin sosyo-ekonomik ve demografik faktörlerinin kredi kartı sahibi olmaları üzerinde etkisini Logit modelle incelemişlerdir. Değişkenler arasından; öğrencinin yaşı, öğrenim türü, ailenin aylık geliri, annenin çalışma durumu, öğrencinin aylık geliri, öğrencinin aylık harcama tutarı değişkenleri kredi kartı sahipliğini belirlemede istatistiksel olarak anlamlı bulunmuştur. 
Xiao vd. (1995), Amerika'da kolej öğrencilerine anket uygulayarak 38 maddelik bir kredi kart1 tutum ölçeği geliştirmiş; Hayhoe vd. (1999), bu ölçeği üçer alt ölçeği olan 12 maddelik diğer bir ölçeğe (Kredi Kartı Kullanım Ölçeği) çevirerek üniverisite öğrencilerinin kredi kartı tutumlarını araştırmışlardır.

Joo vd. (2003:8-15), yüksekokul öğrencilerinin kredi kartı kullanımına etki eden demografik, sosyo-ekonomik, geçmiş deneyimler ve psikolojik özellikler üzerinde durmuşlardır. Öğrencinin eğitim yılı ile kredi kartı kullanımı arasında önemli bir ilişki olduğu; gelir, iş durumu, konaklama durumu ve eğitim dalı ile kredi kartı kullanımı arasında ise önemli bir ilişkinin olmadığı sonucuna ulaşmışlardır. Norvilitis vd. (2006), yüksekokul öğrencilerine 13 farklı türde soru yönelterek kredi kartı kullanım alanlarını tespite çalışmışlardır. Öğrencilerin kredi kartıyla yaptıkları harcama alanları; benzin, elbise ve ayakkabı, manav ve restoran harcamalarıdır. Öğrencilerin büyük bir kısmı okul taksiti ödemeleri ve ders kitabı satın almalarında kredi kartı kullanmaktadır.

\section{GIRESUN ÜNIVERSITESI BANKACILIK VE FINANS BÖLÜMÜ LİSANS ÖĞRENCILERINE YÖNELIK YAPILAN UYGULAMA ÇALIŞMASI}

\subsection{Araştırmanın Amacı}

Bu çalışmayla, bankacılık ve finans alanında dört yıllık eğitim gören üniversite öğrencilerinin kredi kartı sahiplik durumları ve kredi kartı kullanımına yönelik tutumlarının tespitiyle, mevcut akademik yazına ve bankacılık sektörüne güncel bir uygulama örneği sunmak ve katkı sağlamak amaçlanmıştır.

Çalışmada anakütlenin bankacılık ve finans bölümü öğrencilerinden oluşturulmasının nedeni, sözkonusu öğrencilerin iktisadi ve finansal olaylar ve olgular konusunda diğer bölüm öğrencilerine nazaran daha yetkin olacağının düşünülmesi ve kredi kartı konusunda araştırma merakımızın bu gruba yönelik olmasıdır.

\subsection{Araştırmanın Kapsamı}

Bu çalışmanın anakütlesini; 2014-2015 bahar yarıyılında, Giresun Üniversitesi, Görele Uygulamalı Bilimler Yüksekokulu, Bankacılık ve Finans Bölümü'nde, 1. ve 2. öğrenim programında eğitim görmekte olan toplam 736 lisans öğrencisi oluşturmaktadır. Gelişi güzel örneklem yolu ile 250 kişiye anket formu dağıtılmış, geriye dönen ve eksiksiz bilgilerin olduğu toplam 232 adet anket değerlendirmeye tabi tutulmuştur. Örneklem anakütleyi temsil etmektedir.

Araştırmaya yönelik olarak anketlerden elde edilen verilerin işlenmesi ve analizlerde SPSS (Statistical Package for the Social Sciences) programından yararlanılmıştır. Ölçek geliştirmek için faktör analizi uygulanmıştır. 


\subsection{Araştırmanın Yöntemi ve Analiz Uygulama}

$\mathrm{Bu}$ çalışmada veriler anket uygulanması yolu ile elde edilmiştir. Çalışmada kullanılan anketin ilk bölümü, öğrencilerin demografik özellikleri ile kredi kartı sahip olup olmadığı ve kredi kartına dair kişisel görüşlerini tespite yönelik sorulardan oluşturulmuştur. Anketin ikinci bölümü ise, öğrencilerin kredi kartına yönelik duygu ve düşüncelerini öğrenmeye yönelik sorulan ifadelere (13 madde) katılma derecelerinin, 5'li Likert tipi derecelendirmeye (1Kesinlikle Katılmıyorum, 5-Tamamen Katılıyorum) göre cevaplandırmaları istenmiştir. Anket formunda yöneltilen sorular (EK-1), Girginer vd. 2008 yılındaki ölçek çalışmasında yer alan maddelerden alınmıştır (Girginer vd., 2008).

\subsection{Araştırma Bulguları ve Yorum}

Bu bölümde araştırmaya ait bulgular ve yorumlara yer verilecektir.

\subsubsection{Araştırmaya KatılanTüm Öğrencilerin Demografik Özelliklerine İlişkin Bulgular}

Araştırmaya katılan ve anket formunu dolduran 232 bankacılık ve finans öğrencisinin demografik verilerine ilişkin bulgular Tablo 1'de verilmiştir. Tablo1'den görüleceği gibi, anketi cevaplandıran öğrencilerin \%62.9'u k1z, \%37.1'i erkektir. Öğrencilerin aylık harçlık miktarı; öğrencilerin \%50.4'ünün aylık harçlı̆̆ı 300-500TL, \%25.4'nin 500-700TL, \%19.8'nin 700-900TL, \%3'nin 900-1100TL ve \%1.3'nin 1100TLve üzeri seviyededir.

Öğrencilerin sınıf dağılımları açısından ise; \%37.5'lik bir oranla 3.sınıfta okuyan öğrencilerin ilk sırada, \%29.3'lük bir oranla 1.sınıf öğrencilerin ikinci sırada, \%17.2'lık bir oranla 4.sınıf öğrencilerin üçüncü sırada ve \%15.9'lik bir oranla 2.sınıf öğrenciler son sırada yer aldığı görülmektedir. Öğrencilerin \%46.1'i kredi kartına sahip iken, \%53.9'u ise kredi kartına sahip değildir.

Tablo 1. Araştırmaya Katılan Öğrencilerin Demografik Bilgilerine İlişkin Bulgular

\begin{tabular}{|l|l|l|l|}
\hline Demografi Kriteri & Değişken & Sayı & Yüzde \\
\hline \multirow{4}{*}{ Cinsiyet } & Kız & 146 & 62.9 \\
\cline { 2 - 4 } & Erkek & 86 & 37.1 \\
\cline { 2 - 4 } & Toplam & $\mathbf{2 3 2}$ & $\mathbf{1 0 0 . 0}$ \\
\hline \multirow{5}{*}{ Ŏğrencinin Gelir Düzeyi } & $300-500 \mathrm{TL}$ & 117 & 50.4 \\
\cline { 2 - 4 } & $500-700 T L$ & 59 & 25.4 \\
\cline { 2 - 4 } & $700-900$ TL & 46 & 19.8 \\
\cline { 2 - 4 } & $900-1100$ TL & 7 & 3.0 \\
\cline { 2 - 4 } & 1100 TL ve üzeri & 3 & 1.3 \\
\cline { 2 - 4 } & Toplam & $\mathbf{2 3 2}$ & $\mathbf{1 0 0 . 0}$ \\
\hline & 1. Sinıf & 68 & 29.3 \\
\cline { 2 - 4 } & & &
\end{tabular}




\begin{tabular}{|c|c|c|c|}
\hline \multirow{4}{*}{ Sinıf } & 2.Sinif & 37 & 15.9 \\
\hline & 3.Sinif & 87 & 37.5 \\
\hline & 4.Sinif & 40 & 17.2 \\
\hline & Toplam & 232 & 100.0 \\
\hline \multirow{3}{*}{ Kredi Kartı Sahipliği } & Evet & 107 & 46.1 \\
\hline & Hayır & 125 & 53.9 \\
\hline & Toplam & 232 & 100.0 \\
\hline
\end{tabular}

\subsubsection{Kredi Kartı Kullanmayan Öğrencilerin Demografik Özelliklerine İlişkin Bulgular}

Tablo 2 incelendiğinde, kredi kartı kullanmayan öğrencilerin \%68.8'inin kız öğrenci olduğu görülmektedir. Kart kullanmayan bu grubun \%56.8'inin aylık harçlık miktarı 300500TL, \%22.4'ünün 500-700TL, \%18.4'ünün 700-900TL, \%1.6'sının 900-1100TL, \%0.8'inin $1100 \mathrm{TL}$ ve üzeridir. Kredi kartı kullanmayan öğrencilerin sınıf düzeylerine bakacak olursak; \%36'sı üçüncü sınıf, \%33.6's1 1.sınıf, \%18.4'ü 2 sınıf, \%12'si 4.sınıf öğrencisi olduğu görülür.

Tablo 2. Kredi Kartı Kullanmayan Öğrencilerin Demografik Bilgilerine İlişkin Bulgular

\begin{tabular}{|c|c|c|c|}
\hline Demografi Kriteri & Değişken & Sayı & Yüzde \\
\hline \multirow{3}{*}{ Cinsiyet } & $\mathrm{K} 1 \mathrm{z}$ & 86 & 68.8 \\
\hline & Erkek & 39 & 31.2 \\
\hline & Toplam & 125 & 100.0 \\
\hline \multirow{6}{*}{$\begin{array}{l}\text { Öğrencinin Aylik Gelir } \\
\text { (Harçlık) Miktarı }\end{array}$} & $300-500 \mathrm{TL}$ & 71 & 56.8 \\
\hline & 500-700TL & 28 & 22.4 \\
\hline & $700-900 \quad \mathrm{TL}$ & 23 & 18.4 \\
\hline & 900-1100 TL & 2 & 1.6 \\
\hline & 1100 TL ve üzeri & 1 & 0.8 \\
\hline & Toplam & 125 & 100.0 \\
\hline \multirow{5}{*}{ Sinıf } & 1.Sinif & 42 & 33.6 \\
\hline & 2.Sinif & 23 & 18.4 \\
\hline & 3.Sinıf & 45 & 36.0 \\
\hline & 4.Sinif & 15 & 12.0 \\
\hline & Toplam & 125 & 100.0 \\
\hline
\end{tabular}

Kredi kartı kullanmayan öğrencilerin, \%55'i kredi kartına gerek duymadığı için, \%17’si "Param varsa alırım, yoksa almam" düşüncesinden, \%16'sı borçlanmayı 
sevmediğinden, \%9'u kredi kartını sevmediği için, \%3’ü diğer sebeplerden ötürü kredi kartını kullanmadığını belirtmiştir.

Kredi kartı kullanmayan öğrencilere yönelik sorulan "İleride Kredi Kartı Kullanmayı Düşünür müsünüz?" anket sorusuna verilen cevapların dağılımı; öğrencilerin \%46.4'ünün "evet" şıkkını işaretleyerek ileride kredi kartı kullanmayı düşünebileceklerini, \%53.6'sının ise gelecektede kredi kartı kullanımı düşünmedikleri belirlenmiştir. Kredi kartı kullanmayan öğrencilerin ailelerinde kredi kartı kullanan kişi olup olmadığına dair sorulan anket sorusunun cevapları incelendiğinde; öğrencilerin \%64.8'inin ailesinde kredi kartı kullanan bir bireyin olduğu görülmüştür.

\subsubsection{Kredi Kartı Kullanan Öğrencilerin Demografik Bulguları}

Tablo 3 incelendiğinde, kredi kartı kullanan öğrencilerin \%56.1'i kız, \%43.9'u erkektir. Bu grubun %43'ü 300-500TL, \%29'u 500-700TL, \%21.5'i 700-900TL, \%4.7'si 900-1100TL, $\% 1.9$ 'u $1100 \mathrm{TL}$ ve üzeri aylık gelire sahiptir. Öğrencilerin sınıf dereceleri açısından dağılımlarına bakarsak; \%39.3'ü 3.sınıf, \%24.3'ü 1.sınıf, \%23.4'ü 4.sınıf ve \%13.1'i 2.sınıf öğrencisidir. Öğrencilerden tek kredi kartına sahip olanların oranı \%71, iki adet kredi kartına sahip olanlar \%20.6, 3 adet kredi kartı sahibi olanlar \%6.5, 4 ve daha fazla kredi sahibi olanlar \%1.9'dir. Öğrencilerin \%45.8'i 500TL, \%29'u 700TL ve üzeri, \%13.1'i 400TL, \%7.5"i 600TL,\% 4.7 300TL kredi kartı limitine sahiptir. Kredi kartı kullanan öğrencilerin $\% 83.2$ 'sinin ailesinde kredi kartı kullanan bir birey vardır.

Tablo 3. Kredi Kartı Kullanan Öğrencilerin Demografik Bilgilerine İlişkin Bulgular

\begin{tabular}{|l|l|l|l|}
\hline Demografi Kriteri & Değişken & Sayı & Yüzde \\
\hline \multirow{4}{*}{ Cinsiyet } & Kız & 60 & 56.1 \\
\cline { 2 - 4 } & Erkek & 47 & 43.9 \\
\cline { 2 - 4 } & Toplam & $\mathbf{1 0 7}$ & $\mathbf{1 0 0 . 0}$ \\
\hline \multirow{5}{*}{ Öğrencinin Gelir Düzeyi } & $300-500 \mathrm{TL}$ & 46 & 43.0 \\
\cline { 2 - 4 } & 500-700TL & 31 & 29.0 \\
\cline { 2 - 4 } & $700-900$ TL & 23 & 21.5 \\
\cline { 2 - 4 } & 900-1100 TL & 5 & 4.7 \\
\cline { 2 - 4 } & $1100 \mathrm{TL}$ ve üzeri & 2 & 1.9 \\
\cline { 2 - 4 } & Toplam & $\mathbf{1 0 7}$ & $\mathbf{1 0 0 . 0}$ \\
\hline \multirow{5}{*}{ Sınıf } & 1.Sinıf & 26 & 24.3 \\
\cline { 2 - 4 } & 2.Sinıf & 14 & 13.1 \\
\cline { 2 - 4 } & 3. Sinıf & 42 & 39.3 \\
\cline { 2 - 4 } & 4. Sinıf & 25 & 23.4 \\
\cline { 2 - 4 } & Toplam & $\mathbf{1 0 7}$ & $\mathbf{1 0 0 . 0}$ \\
\hline
\end{tabular}




\begin{tabular}{|l|l|l|l|}
\hline \multirow{4}{*}{$\begin{array}{l}\text { Öğrencinin Sahip Olduğu Kredi } \\
\text { Kartı Sayısı }\end{array}$} & 1 Adet & 76 & 71.0 \\
\cline { 2 - 4 } & 2 Adet & 22 & 20.6 \\
\cline { 2 - 4 } & 3 Adet & 7 & 6.5 \\
\cline { 2 - 4 } & 4 Adet & 2 & 1.9 \\
\cline { 2 - 4 } & Toplam & $\mathbf{1 0 7}$ & $\mathbf{1 0 0 . 0}$ \\
\hline \multirow{5}{*}{ Kredi Kartı Limiti } & $300 \mathrm{TL}$ & 5 & 4.7 \\
\cline { 2 - 4 } & 400TL & 14 & 13.1 \\
\cline { 2 - 4 } & 500TL & 49 & 45.8 \\
\cline { 2 - 4 } & 600TL & 8 & 7.5 \\
\cline { 2 - 4 } & $700 \mathrm{TL}$ ve üzeri & 31 & 29.0 \\
\cline { 2 - 4 } & Toplam & $\mathbf{1 0 7}$ & $\mathbf{1 0 0 . 0}$ \\
\hline & Var & 89 & 83.2 \\
\cline { 2 - 4 } & Yok & 18 & 16.8 \\
\cline { 2 - 4 } & Toplam & $\mathbf{1 0 7}$ & $\mathbf{1 0 0 . 0}$ \\
\hline
\end{tabular}

\subsubsection{Kredi Kartı Kullanan Öğrencilerin Diğer Bilgilerine İlişkin Bulgular}

Tablo 4 incelendiğinde, öğrencilerin \%50.5'in taksitli alışveriş avantajı nedeniyle, \%24.3'ün nakit sıkıntısından, \%15.9'un nakit taşımamamak için, \%9.3'ünün diğer sebeplerden ötürü kredi kartı kullandığı görülmektedir. Öğrencilerin \%43'ü giyim harcamalarında, \%11.2'si market alışverişlerinde, \%8.4 elektronik malzeme alımlarında, \%5.6 eğlence ve tatil masraflarında yine \%5.6's1 yemek (restoran) giderlerinde kredi kart1 kulllanımı gerçekleştirmektedir.

Tablo 4.Kredi Kartı Kullanan Öğrencilerin Diğer Bilgilerine İlişkin Bulgular

\begin{tabular}{|l|l|l|l|}
\hline Kriter & Değişken & Sayı & Yüzde \\
\hline \multirow{5}{*}{ Kredi Kartı Kullanım Nedeni } & Nakit Taşımamak İçin & 17 & 15.9 \\
\cline { 2 - 4 } & Taksitli Alışveriş Avantajı & 54 & 50.5 \\
\cline { 2 - 4 } & Nakit Sıkıntısı Nedeniyle & 26 & 24.3 \\
\cline { 2 - 4 } & Diğer & 10 & 9.3 \\
\cline { 2 - 4 } & Toplam & $\mathbf{1 0 7}$ & $\mathbf{1 0 0 . 0}$ \\
\hline \multirow{5}{*}{ Kranı } & Elektronik Malzemeler & 9 & 8.4 \\
\cline { 2 - 4 } & Yemek Giderleri & 6 & 5.6 \\
\cline { 2 - 4 } & Market Alışverişleri & 12 & 11.2 \\
\cline { 2 - 4 } & Eğlence, Tatil masrafları & 6 & 5.6 \\
\cline { 2 - 4 } & Giyim Masrafları & 46 & 43.0 \\
\cline { 2 - 4 } & Sağlık Harcamalar & 0 & 0.0 \\
\cline { 2 - 4 } & & & \\
\hline
\end{tabular}




\begin{tabular}{|c|c|c|c|}
\hline & Diğer (Tümü) & 28 & 26.2 \\
\hline & Toplam & 107 & 100.0 \\
\hline \multirow{5}{*}{ Kart Kullanım Sıklığı } & Birçok alışverişte & 47 & 49.3 \\
\hline & Nakit sıkıntısına düştüğümde & 31 & 29.0 \\
\hline & Yüksek Fiyatlı Alışverişlerde & 23 & 21.5 \\
\hline & Diğer & 6 & 5.6 \\
\hline & Toplam & 107 & 100.0 \\
\hline \multirow{3}{*}{ Kartla Harcamalarda Aşırıya Kaçma } & Evet, Aşırıya Kaçıyorum & 42 & 39.3 \\
\hline & Hayır, Aşırıya Kaçmıyorum & 65 & 60.7 \\
\hline & Toplam & 107 & 100.0 \\
\hline \multirow{3}{*}{ Asgari Ödemeleri Geciktirme } & Evet, Geciktiririm & 33 & 30.8 \\
\hline & Hayır, Geciktirmem & 74 & 69.2 \\
\hline & Toplam & 107 & 100.0 \\
\hline \multirow{3}{*}{$\begin{array}{l}\text { Borcu Ödeyip Kredi Kartını Kapama } \\
\text { Eğilimi }\end{array}$} & Evet & 67 & 62.6 \\
\hline & Hayır & 40 & 37.4 \\
\hline & Toplam & 107 & 100.0 \\
\hline \multirow{3}{*}{$\begin{array}{l}\text { Kredi Kartı Borcunu Çok Geciktirme } \\
\text { (En Az } 3 \text { ay) }\end{array}$} & Evet, Geciktiririm & 18 & 16.8 \\
\hline & Hayır,geciktirmem & 89 & 83.2 \\
\hline & Toplam & 107 & 100.0 \\
\hline \multirow{3}{*}{$\begin{array}{l}\text { Kredi Kartı Kullanımınız Aileniz } \\
\text { Bilgisi Dahilinde mi }\end{array}$} & Evet & 94 & 87.9 \\
\hline & Hayır & 13 & 12.1 \\
\hline & Toplam & 107 & 100.0 \\
\hline \multirow{3}{*}{ Kredi Kartını Önerir misiniz? } & Evet,Öneririm & 53 & 49.5 \\
\hline & Hayır,Önermem & 54 & 50.5 \\
\hline & Toplam & 107 & 100.0 \\
\hline
\end{tabular}

Öğrencilerin \%26.2'si diğer şıkkını işaretleyerek, bu alanların tümünde harcama gerçekleştirdiğini belirtmiştir. Öğrencilerin kredi kartı harcamalarıyla ilgili olarak aşırı kullanım yapıp yapmadıkları sorulmuş; \%60.7'si ise aşırı harcama yapmadığını belirtmiştir. Öğrencilerin \%69.2'si asgari ödemesini geciktirmemektedir. Öğrencilerin \%83.2'si kredi kart1 borcunu çok (üç aydan uzun süre için) geciktirmediği bilgisini vermiştir.

Kredi kartı kullanan öğrencilere "Çok fazla kredi kartı borcunuzun olsa, bu borcu ödeyip karttan kurtulmak ister misiniz?" şeklinde bir soru yöneltilerek kredi kartını kapattırma eğilimleri belirlemek istenmiştir. Öğrencilerin \%62.6's1 soruya "evet" şeklinde yanıt vererek, borçtan ve kredi kartından kurtulmak isteyeceğini belirtmiştir. Öğrencilerin \%87.9'unun ailesi çocuğunun kredi kartı kullanımı konusunda bilgi sahibidir. Kredi kartı kullanan öğrencilerin \%50.5'i kredi kartı kullanımını çevresine önermeyeceğini, \%49.5'i ise önereceğini belirtmiştir. 


\subsubsection{Faktör Analizi Sonuçları}

Kredi kartı kullanan öğrencilerin tutumlarına yönelik faktör analizi gerçekleştirilmiştir. Elde edilen veri setinin faktör analizi için uygun olup olmadığ1 Korelasyon Matris, Kase-Meyer-Olkin (KMO) testi ve Bartlett Küresellik testiyle değerlendirilmiştir. Değişkenler arasındaki korelasyon iyi düzeyde olup, KMO örneklem yeterliliği ölçütümüz (KMO=0,753) iyi olarak ifade edilen bir değer olarak bulunmuştur. $\mathrm{Bu}$ sonuç, örneklem büyüklüğü açısından faktör analizi için veri yapısının uygun olduğunu göstermektedir. Bartlett Küresellik Testi sonucumuz (457,877; p=0,000) olarak bulunmuştur. Bartlett Testi ile korelasyon matrisinin birim matris olup olmadığ korelasyon matrisi birim matristir. $(\mathrm{p}=0,000<0,05)$ olduğundan yokluk hipotezi reddedilir. Bir diğer ifadeyle, evren korelasyon matrisi birim matris değildir. Ayrıca verilerin çok değişkenli normal dağılımdan geldiği varsayımı da böylelikle sağlanmış olur. Bu sonuçlar doğrultusunda veri setinin faktör analizi için uygun olduğuna karar verilmiştir.

Verilerin faktör analizine uygunluğunun tespiti üzerine, ölçeğin yap1 geçerliliğini ve faktör yapısını incelemek amacıyla açımlayıcı faktör analizi, faktörleştirme tekniği olarak ise temel bileşenler analizi kullanılmıştır. Analizlerde faktörlerin her değişken üzerindeki ortak faktör varyansı, maddelerin faktör yükleri, açıklanan varyans oranları ve çizgi grafiği incelenmiştir. Maddelerin faktör yükleri en az 0,30 olarak seçilmiştir. Faktör yapılarını incelemek amacıyla döndürülmüş (varimax) temel bileşenler analizi uygulanmıştır. İkinci aşamada, ölçeklerin faktörlerle ve faktörlerin birbirleriyle ilişkisini belirlemek için pearson korelasyon katsayısından faydalanılmıştır.

Faktör analizinde önce toplu olarak ankette sorulan 13 maddeye ilişkin güvenilirlik testi uygulanmış, Cronbach's Alpha değeri $(\alpha=0,669)$ bulunmuştur. Ardından güvenilirliliği bozduğu düşünülen ifadeler analizden çıkarılmış, geriye kalan 8 ifadenin toplu bir biçimde güvenilirliği analiz edildiğinde, Cronbachs' Alpha değeri $(\alpha=0,809)$ hesaplanarak, yüksek derecede güvenilirlik seviyesinin sağladığı görülmüştür. Ortaklık unsuru yüksek olan 8 değişken ile gerçekleştirilen faktör analizi yapılmış, sonuçlar Tablo 5'de verilmiştir.

Tablo 5. Açımlayıcı Faktör Analizi Sonuçları

\begin{tabular}{|l|l|l|l|}
\hline Maddeler & $\begin{array}{l}\text { Faktör1 } \\
\text { (Duygusal } \\
\text { Boyut) }\end{array}$ & $\begin{array}{l}\text { Faktör2 } \\
\text { (Davranışsal } \\
\text { Boyut) }\end{array}$ & $\begin{array}{l}\text { Faktör3 } \\
\text { (Güven } \\
\text { Boyutu) }\end{array}$ \\
\hline Soru 3: Kredi kartına sahip olmayı seviyorum. & 0.931 & & \\
\hline Soru 1: Kredi kartım beni mutlu ediyor. & 0.906 & & \\
\hline Soru 2: Kredi kartını kullanmayı seviyorum. & 0.900 & 0.915 & \\
\hline Soru 6: Daha çok kredi kartım olsun isterim. & & 0.891 & \\
\hline $\begin{array}{l}\text { Soru 7: Kredi kartının tüm çeşitlerini denemeyi } \\
\text { severim. }\end{array}$ & & & \\
\hline
\end{tabular}




\begin{tabular}{|c|c|c|c|}
\hline Soru 12: Kredi kartsız yapamam & & 0.605 & \\
\hline Soru 10: Kredi Kartı Risksizdir. & & & 0.870 \\
\hline Soru 9: Kredi Kartı Güvenlidir. & & & 0.850 \\
\hline \multicolumn{4}{|l|}{ Özdeğerler } \\
\hline Varyans Açıklama Oranı (\%) & 44.895 & 20.337 & 15.566 \\
\hline Cronbach's Alpha $\alpha$ & 0.931 & 0.779 & 0.713 \\
\hline Cronbach's Alpha $\alpha$ (3 Faktör Birlikte) & \multicolumn{3}{|l|}{0.809} \\
\hline \multicolumn{4}{|l|}{ KMO $=0,753$} \\
\hline \multicolumn{4}{|c|}{ Bartlett sınaması değeri $=457,877 ; p=0,000<0,05$} \\
\hline
\end{tabular}

Faktör analizi işlemleriyle ölçeğin alt boyutlarının belirlenmesi ve boyutların toplam varyansın ne kadarını yansıttığı görülmek istenmiştir. Dik döndürme sonrasında elde edilen, açımlayıcı faktör analizi sonuçlarına göre; ölçeğin özdeğeri 1'den büyük olan 4 faktör altında toplandığı belirlenmiştir. Faktör sayısını belirlemede Kaiser'in (1960) özdeğer $\geq 1$ kuralı dikkate alınmıştır. Bu 3 faktörün varyansa yaptığı katkısı yüzde olarak incelenirse; birinci faktörün "Duygusal Boyut" varyansa yaptı̆̆ katk1 \%44.895, ikinci faktörün "Davranışsal Boyut" \%20.337, üçüncü faktörün "Güven Boyutu" \%15.566'dir. Her bir faktörün varyansa yaptığı katkının birikimli yüzdesi \%80.799'dur.

\subsubsection{Kredi Kartı Kullanan Öğrencilere Yönelik Uygulanan Diğer Testlerin Bulguları}

Açımlayıcı faktor analizi sonucunda belirlenen alt boyutların, kredi kartı kullanan öğrencilerin cinsiyet değişkenine göre kredi kartı tutumlarının farklılık gösterip göstermediğini incelemek için Mann-Whitney U testi, aylık gelirleri ve sınıf seviylerine göre kredi kartı tutumlarının farklılık göstermediğini belirlemek için ise Kruskal -Wallis H testi yapılmıştır.

Tablo 6. Kredi Kartı Kullanan Öğrencilerin Cinsiyet Değişkeni ile Kredi Kartına Eğilimi Arasındaki Farklılıklarının Mann Whitney U Testi Sonucu

\begin{tabular}{|l|l|l|l|l|l|}
\hline & Cinsiyet & N & Sıra Değer Ortalama & Mann-Whitney U & P \\
\hline Duygusal & Kız & 60 & 54.14 & 1401.500 & 0.957 \\
Boyut & Erkek & 47 & 53.82 & & \\
\hline Davranışsal & Kız & 60 & 55.18 & 1339.500 & 0,652 \\
Boyut & Erkek & 47 & 52.50 & & \\
\hline Güven & Kız & 60 & 47.23 & 1003.500 & $\mathbf{0 . 0 0 9 *}$ \\
Boyutu & Erkek & 47 & 62.65 & & \\
\hline * p $\mathbf{0 . 0 5}$ & \multicolumn{7}{|l}{} \\
\hline
\end{tabular}

Mann-Whitney- U testi sonucunda, kredi kartı kullanan öğrencilerin cinsiyetinin kredi kartına yönelik "Güven boyutu" üzerinde anlamlı bir etkisinin olduğu ( $p=0,009<0.05)$, duygusal ve davranışsal boyut üzerinde ise anlamlı bir etkisinin olmadığı belirlenmiştir. 
Güven boyutunun sıra ortalamaları dikkate alındığında, erkek öğrencilerin kız öğrencilere göre kredi kartına güven eğilimlerinin daha yüksek olduğu görülmektedir.

Tablo 7. Öğrencilerin Aylık Gelirleri ile Kredi Kartına Eğilimleri Arasındaki Farkl1lıklarının Kruskal-Wallis Testi Sonucu

\begin{tabular}{|c|c|c|c|c|c|}
\hline & $\begin{array}{l}\text { Öğrencinin } \\
\text { Seviyesi }\end{array}$ & $\mathbf{N}$ & $\begin{array}{ll}\text { Sira } \\
\text { Ortalama }\end{array}$ & $\mathrm{X}^{2}$ & $\mathbf{P}$ \\
\hline \multirow{4}{*}{$\begin{array}{l}\text { Duygusal } \\
\text { Boyut }\end{array}$} & 500 TL'ye kadar & 46 & 48.50 & 2.917 & 0.233 \\
\hline & 500-700TL & 31 & 60.29 & & \\
\hline & 700TL ve üzeri & 30 & 55.93 & & \\
\hline & Toplam & 107 & & & \\
\hline \multirow{4}{*}{$\begin{array}{l}\text { Güven } \\
\text { Boyutu }\end{array}$} & 500 TL'ye kadar & 46 & 46.34 & 5.441 & $0.066^{* *}$ \\
\hline & $500-700 \mathrm{TL}$ & 31 & 57.52 & & \\
\hline & 700TL ve üzeri & 30 & 62.12 & & \\
\hline & Toplam & 107 & & & \\
\hline \multirow{4}{*}{$\begin{array}{l}\text { Davranışsa } \\
\text { l Boyut }\end{array}$} & 500 TL'ye kadar & 46 & 48.21 & 5.319 & $0.070^{* *}$ \\
\hline & 500-700TL & 31 & 52.42 & & \\
\hline & 700TL ve üzeri & 30 & 64.52 & & \\
\hline & Toplam & 107 & & & \\
\hline \multicolumn{6}{|l|}{${ }^{* *} p<0.10$} \\
\hline
\end{tabular}

Kruskal Wallis H Testi sonuçlarına göre öğrencinin aylık gelir durumu ile kredi kartına yönelik duygusal, davranışsal ve güven alt boyutlarının bakış açısı üzerinde anlamlı bir fark yoktur (p>0.05). Sonuçlar \%10 anlamlılık seviyesinde değerlendirilirse; öğrencilerin gelirleriyle kart tutumuna yönelik alt boyutlardan "Güven boyutu" ( $\left.X^{2}=5.441 ; s d=2 ; 0.066\right)$, "Davranışsal Boyut" bakış açısı üzerinde anlamlı bir fark olduğu görülür $\left(X^{2}=5.319\right.$; $\mathrm{sd}=2 ; 0.070)$. Belirlenen farklılığın hangi gruptan kaynaklandığını tespiti için tamamlayıcı karşılaştırma tekniklerine geçilmiştir. Bu amaç için özel bir tekniğin bulunmamasından ötürü ikili karşılaştırmada kullanılan Mann-Whitney-U testi uygulanmıştır.

Tablo 8'deki ikili karşılaştırma sonuçlarına göre; aylık geliri 500TL'ye kadar olan öğrenci grubu ile aylık geliri 700TL ve üzeri olan öğrenci grubu arasında kredi kartı ölçeğimizin güven boyutu bakış açısı üzerinde anlamlı bir fark bulunmuştur ( $p=0,029<0,05)$. Grupların sıra ortalamaları dikkate aldığımızda, aylık geliri 700TL ve üzeri olan öğrenci grubunun, geliri 500TL'ye kadar olan öğrenci grubuna göre daha fazla risk alma eğiliminde olduğu söylenebilir. Geliri 500TL'ye kadar olan öğrenci grubu ile geliri 700TL ve üzeri olan öğrenci grubu arasında kredi kartı ölçeğimizin davranışsal boyutu bakış açısı üzerinde de anlamlı bir fark bulunmuştur $(\mathrm{p}=0,023<0,05)$. Grupların sıra ortalamaları dikkate aldığımızda, 
aylık geliri 700TL ve üzeri öğrenci grubunun kredi kartına yönelik davranışsal eğiliminin, geliri 500TL'ye kadar olan öğrenci grubuna göre daha fazla olduğu söylenebilir.

Tablo 8. Güven ve Davranışsal Alt BoyutlarınınÖğrenci Aylık Gelirine Göre Anlamlı Farklılığının Tespiti İçin Mann Whitney U-Testi İkili Karşılaştırma Sonuçları

\begin{tabular}{|c|c|c|c|c|c|}
\hline & Gelir Grupları & $\mathbf{N}$ & $\begin{array}{l}\text { Sira } \\
\text { Ortalama } \\
\text { Değer }\end{array}$ & $\mathbf{U}$ & $\mathbf{P}$ \\
\hline \multirow{4}{*}{ Güven Boyutu } & $\begin{array}{l}\text { 500TL'ye kadar (Grup 1) } \\
\text { 500-700TL (Grup 2) } \\
\text { Toplam }\end{array}$ & $\begin{array}{l}46 \\
31 \\
77\end{array}$ & $\begin{array}{l}35.73 \\
43.85\end{array}$ & 562.500 & 0.112 \\
\hline & $\begin{array}{l}\text { 500TL'ye kadar (Grup 1) } \\
\text { 700TL ve üzeri (Grup 3) } \\
\text { Toplam }\end{array}$ & $\begin{array}{l}46 \\
30 \\
76\end{array}$ & $\begin{array}{l}34.11 \\
45.23\end{array}$ & 488.000 & 0.029* \\
\hline & $\begin{array}{l}\text { 500-700TL (Grup 2) } \\
\text { 700TL ve üzeri (Grup 3) } \\
\text { Toplam }\end{array}$ & $\begin{array}{l}31 \\
30 \\
61\end{array}$ & $\begin{array}{l}29.66 \\
32.38\end{array}$ & 423.500 & 0.541 \\
\hline & Gelir Grupları & $\mathbf{N}$ & $\begin{array}{l}\text { Sira } \\
\text { Ortalama } \\
\text { Değer }\end{array}$ & $\mathbf{U}$ & $\mathbf{P}$ \\
\hline \multirow{3}{*}{$\begin{array}{l}\text { Davranışsal } \\
\text { Boyut }\end{array}$} & $\begin{array}{l}\text { 500TL'ye kadar (Grup 1) } \\
\text { 500-700TL (Grup 2) } \\
\text { Toplam }\end{array}$ & $\begin{array}{l}46 \\
31 \\
77\end{array}$ & $\begin{array}{l}37.76 \\
40.84\end{array}$ & 656.000 & 0.543 \\
\hline & $\begin{array}{l}\text { 500TL'ye kadar (Grup 1) } \\
\text { 700TL ve üzeri (Grup 3) } \\
\text { Toplam }\end{array}$ & $\begin{array}{l}46 \\
30 \\
76\end{array}$ & $\begin{array}{l}33.95 \\
45.48\end{array}$ & 480.000 & 0.023* \\
\hline & $\begin{array}{l}\text { 500-700TL (Grup 2) } \\
\text { 700TL ve üzeri (Grup 3) } \\
\text { Toplam }\end{array}$ & $\begin{array}{l}31 \\
30 \\
61\end{array}$ & $\begin{array}{l}27.58 \\
34.53\end{array}$ & 359.000 & 0.122 \\
\hline
\end{tabular}


Tablo 9, kredi kartı kullanan öğrencilerin sınıf seviyesiyle kredi kartına yönelik duygusal, davranışsal ve güven boyutlarının bakış açısı üzerinde anlamlı bir fark ise bulunamamıştır ( $p$ >0.05); ancak sonuçlar \%10 anlamlılık seviyesinde değerlendirilidiğinde öğrencilerin sınıf seviyesiyle kart tutumuna yönelik boyutlardan "Güven boyutu" ( $\mathrm{X}^{2}=6.864$; sd=3; 0.076) bakış açısı üzerinde anlamlı bir fark olduğu görülür. Farklılığın hangi gruptan kaynaklandığını tespiti için ikili karşılaştırmada tercih edilen Mann-Whitney- U testi uygulanmıştır.

Tablo 9. Öğrencilerin Sınıf Seviyeleriyle Kredi Kartına Eğilimleri Arasındaki Farklılıklarının Kruskal-Wallis Testi Sonucu

\begin{tabular}{|c|c|c|c|c|c|}
\hline & Öğrencinin Gelir Seviyesi & $\mathbf{N}$ & Sura Değer Ortalama & $\mathrm{X}^{2}$ & $\mathbf{P}$ \\
\hline $\begin{array}{l}\text { Duygusal } \\
\text { Boyut }\end{array}$ & $\begin{array}{l}\text { 1.SINIF } \\
\text { 2.SINIF } \\
\text { 3.SINIF } \\
\text { 4.SINIF }\end{array}$ & $\begin{array}{l}26 \\
14 \\
42 \\
25\end{array}$ & $\begin{array}{l}53.79 \\
54.18 \\
52.06 \\
57.38\end{array}$ & 0.476 & 0.924 \\
\hline $\begin{array}{l}\text { Güven } \\
\text { Boyutu }\end{array}$ & $\begin{array}{l}\text { 1.SINIF } \\
\text { 2.SINIF } \\
\text { 3.SINIF } \\
\text { 4.SINIF }\end{array}$ & $\begin{array}{l}26 \\
14 \\
42 \\
25\end{array}$ & $\begin{array}{l}41.79 \\
51.61 \\
56.95 \\
63.08\end{array}$ & 6.864 & $0.076^{* *}$ \\
\hline $\begin{array}{l}\text { Davranışsal } \\
\text { Boyut }\end{array}$ & $\begin{array}{l}\text { 1.SINIF } \\
\text { 2.SINIF } \\
\text { 3.SINIF } \\
\text { 4.SINIF }\end{array}$ & $\begin{array}{l}26 \\
14 \\
42 \\
25\end{array}$ & $\begin{array}{l}52.42 \\
62.14 \\
53.85 \\
51.34\end{array}$ & 1.261 & 0.738 \\
\hline$* * p<0.10$ & & & & & \\
\hline
\end{tabular}

Tablo 10. Güven Alt Boyutunun Öğrenci Sınıf Seviyelerine Göre Anlamlı Farklılığının Tespiti İçin Mann Whitney U-Testi İkili Karşılaştırma Sonuçları

\begin{tabular}{|c|c|c|c|c|c|}
\hline & $\begin{array}{ll}\text { Öğrencinin } & \text { Sınıf } \\
\text { Seviyesine } & \text { Göre } \\
\text { Gruplar } & \\
\end{array}$ & $\mathbf{N}$ & $\begin{array}{l}\text { Sira } \\
\text { Değer }\end{array}$ & $\begin{array}{l}\text { Mann } \\
\text { Whitney-U }\end{array}$ & $\mathbf{P}$ \\
\hline \multirow[t]{2}{*}{$\begin{array}{l}\text { Güven } \\
\text { Boyutu }\end{array}$} & $\begin{array}{l}\text { 1.SINIF } \\
\text { 2.SINIF }\end{array}$ & $\begin{array}{l}26 \\
14\end{array}$ & $\begin{array}{l}19.37 \\
22.61\end{array}$ & 152.500 & 0.396 \\
\hline & TOPLAM & 40 & & & \\
\hline \multirow[t]{2}{*}{$\begin{array}{l}\text { Güven } \\
\text { Boyutu }\end{array}$} & $\begin{array}{l}\text { 1.SINIF } \\
\text { 3.SINIF }\end{array}$ & $\begin{array}{l}26 \\
42\end{array}$ & $\begin{array}{l}28.38 \\
38.29\end{array}$ & 387.000 & 0.041* \\
\hline & TOPLAM & 68 & & & \\
\hline
\end{tabular}




\begin{tabular}{|c|c|c|c|c|c|}
\hline $\begin{array}{l}\text { Güven } \\
\text { Boyutu }\end{array}$ & $\begin{array}{l}\text { 1.SINIF } \\
4 . \text { SINIF }\end{array}$ & $\begin{array}{l}26 \\
25\end{array}$ & $\begin{array}{l}21.04 \\
31.16\end{array}$ & 196.000 & $0.014^{*}$ \\
\hline & TOPLAM & 51 & & & \\
\hline \multirow[t]{2}{*}{$\begin{array}{l}\text { Güven } \\
\text { Boyutu }\end{array}$} & $\begin{array}{l}\text { 2.SINIF } \\
\text { 3.SINIF }\end{array}$ & $\begin{array}{l}14 \\
42\end{array}$ & $\begin{array}{l}26.46 \\
29.18\end{array}$ & 265.500 & 0.580 \\
\hline & TOPLAM & 56 & & & \\
\hline \multirow[t]{2}{*}{$\begin{array}{l}\text { Güven } \\
\text { Boyutu }\end{array}$} & $\begin{array}{l}\text { 2.SINIF } \\
\text { 4.SINIF }\end{array}$ & $\begin{array}{l}14 \\
25\end{array}$ & $\begin{array}{l}17.54 \\
21.38\end{array}$ & 140.500 & 0.303 \\
\hline & TOPLAM & 39 & & & \\
\hline \multirow[t]{2}{*}{$\begin{array}{l}\text { Güven } \\
\text { Boyutu }\end{array}$} & $\begin{array}{l}\text { 3.SINIF } \\
\text { 4.SINIF }\end{array}$ & $\begin{array}{l}42 \\
25\end{array}$ & $\begin{array}{l}32.49 \\
36.54\end{array}$ & 461.500 & 0.399 \\
\hline & TOPLAM & 67 & & & \\
\hline${ }^{*} p<0.05$ & & & & & \\
\hline
\end{tabular}

Tablo 10'daki karşılaştırma sonuçlarına göre; 1. sınıfta okuyan öğrenci grubuyla 3. sinıfta okuyan öğrenci grubu arasında $(\mathrm{p}=0,041<0,05), 1$. sinıfta okuyan öğrenci grubuyla 4. sınıfta okuyan öğrenci grubu arasında $(\mathrm{p}=0,014 \prec 0,05)$, kredi kartı ölçeğimizin güven alt boyutu bakış açısı üzerinde anlamlı bir fark bulunmuştur.

\section{SONUÇ}

Giresun Üniversitesi Görele Uygulamalı Bilimler Yüksekokulu Bankacılık ve Finans Bölümü lisans öğrencilerinin kredi kartı sahipliği ve kredi kartı kullanımına yönelik yapılan bu çalışmada aşağıdaki sonuçlara ulaşılmıştır:

(a) Ankete katılan öğrencilerin \%46.1's1 kredi kartı kullanmakta, \%53.9'u kullanmamaktadır. Öğrencilerin \%50.4'ü aylık 300-500TL gelire (harçlık) sahiptir ve öğrencilerin \%62.9'u kız, \%37.1'i erkektir. Çalışmaya en çok 3.sınıf öğrencileri (\%37.5), en az 2. sınıf öğrencileri (\%15.9) katılmıştır.

(b) Kredi kartı sahibi olmayan öğrencilerin büyük bir çoğunluğu kız öğrencilerden (\%68.8) oluşmakta olup, yine bu öğrencilerin büyük bir çoğunluğu (\%36's1) üçüncü sınıf öğrencisidir. Öğrencilerin \%55.2'si kredi kartına gerek duymadığı için, \%16.8 "param varsa tüketim yaparım" görüşünden, \%16'sı borçlanmayı sevmediğinden, \%8.8'i kredi kartını sevmediğinden, geri kalan ise diğer sebeplerden ötürü kredi kartını kullanmamaktadır. Kart kullanmayan öğrencilerin \%64.8'inin ailesinde kredi kartı kullanan bir birey olmasına karşın gelecekte de kredi kartı kullanımını (öğrencilerin \%53.6's1) düşünmemektedir.

(c) Kredi kartı kullanan öğrencilerin içerisinde k1z öğrencilerin (\%56.1), erkek öğrencilerden (\%43.9) daha fazla olduğu ve kredi kartı kullanan öğrencilerin \%43'ünün aylık geliri 300-500TL olduğu tespit edilmiştir. Kredi kartı kullanan öğrencilerin \%39.3'ü 3.sınıf, 
\%24.3'ü 1.sınıf, \%23.4'ü 4.sınıf ve \%13.1'i 2. sınıf öğrencisidir. Öğrencilerin \%71'i tek kredi kartına sahiptir, sahip olunan kartların \%45.8'inin limiti 500TL'dir. Kredi kartı kullanan öğrencilerin \%83.2'sinin ailesinde kredi kartı kullanan bir kişi vardır. Bu öğrencilerin \%50.5'in taksitli alışveriş avantajı nedeniyle, \%24.3'ün nakit sıkıntısından ötürü, \%15.9'un nakit taşımamamak için, \%9.3'ünün diğer sebeplerden ötürü kredi kartı kullanımı gerçekleştirdiği görülmüştür. Öğrencilerin \%43'ü giyim harcamalarında en fazla kredi kartı kullanırken, en az (\%5.6'sı) restoran giderlerinde kullanmaktadır.

(d) Kredi kartı kullanan öğrencilerin \%60.7'si kredi kartı harcamalarında aşırıya kaçmamakta ve \%69.2'si asgari ödemesini zamanında yapmaktadır. Öğrencilerin \%87.9'unun ailesi çocuğunun kredi kartı kullanımı hakkında bilgi sahibidir. Kredi kartı kullanan öğrencilerin \%50.5'i kredi kartı kullanımını çevresine önermeyeceğini belirtmiştir.

(e) Çalışmamızda, kredi kartı kullanan öğrencilerin cinsiyet değişkeninin kredi kartına yönelik "Güven Boyutu"üzerinde anlamlı bir etki tespit edilirken, duyusal ve davranışsal boyut üzerinde anlamlı bir etki bulunamamıştır. Erkek öğrencilerin kredi kartına güven eğilimleri kız öğrencilere göre daha yüksek olduğu sonucuna ulaşılmıştır. Çiçek ve Demirdelen'in (2010) çalışmasında da benzer sonuca ulaşmştır.

(f) Öğrencilerin aylık harçlıkları ile kredi kartı tutum alt boyutlarının bakış açısı üzerinde $\% 5$ anlamlılık düzeyinde bir fark bulunamazken, $\% 10$ anlamll1ık seviyesinde "güven boyutu" üzerinde bir fark belirlenmiştir. Geliri yüksek olan grubun, geliri düşük olan gruba göre daha fazla risk alma tutumu gösterdiği belirlenmiştir.

(g) Eğitimine yeni başlayanlar ile daha üst sınıflar arasında kredi kartının güven boyutu bakış açısı üzerinde anlamlı bir fark görülmüştür. Bu durumu; eğitim seviyesi yükseldikçe, finansal bilgi düzeyi arttıkça finansal ürünlere karşı güvensizlik sorunu aşılmaktadır şeklinde yorumlayabiliriz.

$\mathrm{Bu}$ çalışmayla, bankacılık ve finans eğitimi gören lisans öğrencilerinin kredi kartı tutumlarını incelemek, öğrencilerin kredi kartına sahip olma durumları ve kredi kartı kullanımlarına dair bilgiler elde etmek istenmiştir. Kredi kartı kullanmayan öğrencilerin demografik özellikleri ve kart kullanmama nedenleri ile kredi kartı kullanan öğrencilerin kart kullanım sebepleri, harcama alanları, kart kullanım sıklığı, asgari ödeme ve borçların aşırı geciktirilmesi, kredi kartı sayısı, ileride kredi kartı kullanımı niyeti ve diğer sorular yöneltilerek öğrencilerin kredi kartı kullanımına yönelik bilgilerin toplanması ve paylaşılması başta mevcut literature katkı yapacağı gibi bankacılık olmak üzere bir çok sektöre faydalı olacağı düşünülmektedir. Bundan sonraki çalışmalarda, anket uygulamaları daha farklı ve büyük örneklemler üzerinde gerçekleştirilerek, güncel çalışmalar yapılabilir. 


\section{KAYNAKLAR}

Aşan, Zerrin (2007), “Kredi Kartı Kullanan Müşterilerin Sosyo Ekonomik Özelliklerinin Kümeleme Analizi ile İncelenmesi”, Dumlupınar Üniversitesi Sosyal Bilimler Dergisi, Sayı.17, ss.1-12.

Can, Bahar Aydın (2013), “Meslek Yüksekokulu Öğrencilerinin Kredi Kartı Kullanım Alışkanlıklarını Belirlemeye Yönelik Bir Pilot Araştırma", Mevzuat Dergisi, Say1.185, May1s, ss.1-13.

Cengiz, Ekrem (2009), "Bireylerin Kredi Kartlarını Değiştirme Tutumları", Fırat Üniversitesi Sosyal Bilimler Dergisi, Cilt 19, Say1.2, ss.179-196.

Çiçek, Recep - Demirdelen, Kemal (2010), "Kredi Kartı Kullanıcılarının Kart Tercihlerini Değerlendirmeye Yönelik Bir Araştırma: Niğde Üniversitesi Akademisyenleri Örneği", Yönetim:İstanbul Üniversitesi İşletme İktisadı Enstitüsü Dergisi, Sayı. 66, ss.1-20.

Durukan, Tülin - Elibol, Halil - Özhavzal1, Müzeyyen (2005), "Kredi Kartlarındaki Taksit Uygulamasının Tüketicinin Harcama Alışkanlıkları Üzerindeki Etkisini Ölçmeye Yönelik Bir Araştırma (Kırıkkale İli Örneği)", Selçuk Üniversitesi Sosyal Bilimler Enstitüsü Dergisi, Sayı.13, ss.143-153.

Evans, David. S. (2004), "The Growth and Diffusion of Credit Cards in Society", Payment Card Economics Review, Vol.2, ss.59-76.

Girginer, Nuray - Çelik, Arzum Erken - Uçkun, Nurullah (2008), "Eskişehir Osmangazi Üniversitesi İktisadi ve İdari Bilimler Fakültesi Öğrencilerinin Kredi Kartı Kullanımlarına Yönelik Bir Araştırma", Anadolu Üniversitesi Sosyal Bilimler Dergisi, No.8, Say1.1, ss.193-208.

Gözener, Bilge - Sayıl1, Murat (2013), "Gaziosmanpaşa Üniversitesi Taşlıçiftlik Yerleşkesindeki Öğrencilerin Kredi Kartı Kullanımı Üzerine Bir Araştırma", Çankırı Karatekin Üniversitesi Sosyal Bilimler Enstitüsü Dergisi, Cilt.4, Say1.1, ss.181-198.

Hayhoe, Celia Ray - Leach, Lauren - Turner, Pamela R. (1999), "Discriminating the Number of Credit Cards Held by College Students Using Credit and Money Attitudes", Journal of Economic Psychology, Volume.20, Issue. 6, pp.643-656.

Joo, So-Hyun - Grable, John E. - Dorothy. C. Bagwell (2003), "Credit Card Attitudes and Behaviors of College Students", College Student Journal, Volume.37, No.3, September, pp.8-15.

Karamustafa, Kurtuluş - Biçkes, Durdu Mehmet (2003), "Kredi Kartı Sahip ve Kullanıcılarını Kredi Kartı Kullanımlarını Değerlendirmeye Yönelik Nevşehir İlinde Yapılan Bir Araştırma", Erciyes Üniversitesi Sosyal Bilimler Enstitüsü Dergisi, Say1.2, ss.91-113.

Kaya, Feridun (2009), Kredi Kartları - 5464 Sayılı Banka ve Kredi Kartları Kanunu İlaveli, 2. Bask1, Beta Yayın, İstanbul. 
Keskin, Dilara H. - Koparan, Emrah (2010). "Üniversite Öğrencilerinin Kredi Kart1 Sahipliğini Belirleyen Faktörler", Eskişehir Osmangazi Üniversitesi İİBF Dergisi, Cilt.5, Sayı.1, Nisan, ss.111-129.

Norvilitis, Jill M. - Mervin, Michelle. M. - Osberg, Timothy M. - Roehling, Patricia V. Young, Paul - Kamas, Michele, M. (2006), "Personality Factors, Money Attitudes, Financial Knowledge and Credit-Card Debt in College Students”, Journal of Applied Social Psychology, Volume.36, Issue.6, June, pp.1395-1413.

Suher, Hasan Kemal - Ulusu, Yeşim - Bir, Ali Atıf (2014), "Kredi Kartı Kullanımına Yönelik Genel Tutumu Etkileyen Faktörler: Üniversite Öğrencilerine Yönelik Bir Araştırma", Arel Üniversitesi İletişim Çalışmaları Dergisi, Sayı.6, ss.1-18.

Oktay, Erkan - Özen, Üstün - Alkan, Ömer (2009), "Kredi Kartı Sahipliğinde Etkili Olan Faktörlerin Araştırılması: Erzurum Örneği", Dokuz Eylül Üniversitesi İ.İ.B.F. Dergisi, Cilt. 24, Say1.2, May1s, ss.1-22.

Örücü, Edip (2003), "Kredi Kartı Kullanımının Tüketici Davranışları Üzerine Olan Etkisisnin Kamu Çalışanları Açısından İncelenmesi: Manisa Orman İşletmesi Çalışanları Örneği", Mevzuat Dergisi, Sayı.68, Ağustos, ss.1-10.

Özkul, Fatma Ulucan - Tapşın, Gülçin (2010). "Kredi Kartı Kullanımı ile Kullanılabilir Gelirin Tüketim Üzerindeki Etkisi ve Türkiye Ekonomisi Üzerine Bir Ampirik Çalışma", MUFAD Muhasebe ve Finansman Dergisi, Sayı. 47, Temmuz, ss.138-153.

Şener, Arzu - Güven, Seval (2005), "Yaşlıların Kredi Kartı Kullanımına İlişkin Davranışları ve Karşılaşıkları Sorunlar", Türk Geriatri Dergisi, Cilt.8, Sayı.4, ss.184-194.

Xiao, Jing J. - Noring, Franziska E. - Anderson, Joan G. (1995), "College Students' Attitudes Towards Credit Cards", Journal of Consumer Studies and Home Economics, Vol.19, Issue.2, pp.155-174.

Yayar, Rüştü - Karaca, Süleyman Serdar - Turgut, Ahmet (2011), Üniversite Öğrencilerinin Kredi Kartı Sahibi Olmaları Üzerinde Etkili Olan Faktörler: Gaziosmanpaşa ve İnönü Üniversite’lerinden Ampirik Bulgular, Akademik Yaklaşımlar Dergisi, Cilt.2, Sayı.1, ss.152-169. 
EK-1: Ölçeğe İlişkin Maddeler (Anket Formunun 2.Bölümü)

\begin{tabular}{|c|c|c|c|c|c|}
\hline Kredi Kartı ile ilgili görüşleriniz & 量 & 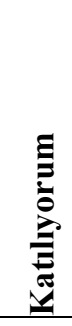 & 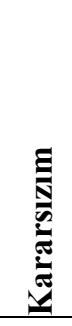 & 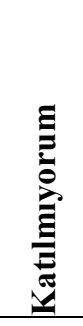 & 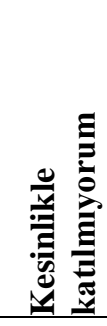 \\
\hline 1. Kredi kartım beni mutlu ediyor. & 5 & 4 & 3 & 2 & 1 \\
\hline 2. Kredi kartı kullanmayı seviyorum. & 5 & 4 & 3 & 2 & 1 \\
\hline 3. Kredi kartına sahip olmayı seviyorum. & 5 & 4 & 3 & 2 & 1 \\
\hline 4. Kredi kartını fazla kullanmak fazla borç demektir. & 5 & 4 & 3 & 2 & 1 \\
\hline $\begin{array}{l}\text { 5. Kredi kartı kullandığım için borcum her geçen gün } \\
\text { artıyor. }\end{array}$ & 5 & 4 & 3 & 2 & 1 \\
\hline 6. Daha çok kredi kartım olsun isterim. & 5 & 4 & 3 & 2 & 1 \\
\hline 7. Kredi kartlarının tüm çeşitlerini denemeyi severim. & 5 & 4 & 3 & 2 & 1 \\
\hline 8. Kredi kartı sadece acil durumlarda kullanılmalıdır. & 5 & 4 & 3 & 2 & 1 \\
\hline 9.Kredi kartları güvenlidir. & 5 & 4 & 3 & 2 & 1 \\
\hline 10. Kredi kartları risksizdir. & 5 & 4 & 3 & 2 & 1 \\
\hline $\begin{array}{l}\text { 11. Kredi kartını kullanırken bütçemin üzerinde } \\
\text { harcama yapacağımdan korkarım. }\end{array}$ & 5 & 4 & 3 & 2 & 1 \\
\hline 12. Kredi kartsız yapamam. & 5 & 4 & 3 & 2 & 1 \\
\hline 13. Kredi kartı yararlıdır. & 5 & 4 & 3 & 2 & 1 \\
\hline
\end{tabular}

